\title{
Influence on The Level Riders Motorcycle Accident Traffic with Traffic Methods of Conflict Technique (TCT) (Case Study: Jalan Raya Narogong Bekasi City)
}

\author{
Andri Irfan Rifai and Finsa Aziz Fernanda \\ Faculty of Engineering, University of Mercu Buana Jakarta, Indonesia \\ andrirfan@yahoo.com, finsaaziz@gmail.com
}

\begin{abstract}
Abstrak
The increasing number of traffic accidents can be caused by drivers, vehicles, highways, and the environment. In Indonesia, traffic accidents become one of the problems in the transportation sector. Prevention is done during this time to anticipate accidents only based on the data of the accident quantity that has occurred. Though factors or incidents that can cause accidents to become the biggest contributor in the event of accidents. For example, driving a vehicle in an unorderly manner, the pace of the vehicle with the above-average velocity set traffic rules, and sudden vehicle maneuvers. This research is done by identifying and analyzing the behavior of motorcyclists who affect accidents and applying TCT methods to observation data at points that become potential locations Against accidents. The research location is on the Narogong Highway which is divided into 2 segments. In Segment 1 begins at junction four Cipendawa (after the flyover Simpang Cipendawa) until the junction of the three Gg. Sawo (Bantar Gebang Market). Next, in Segment 2 starts from junction three of Gg. Sawo (Bantar Gebang Market) until the three houses of Vida housing. The results showed that the research location had potential that could cause the accident to be front-side on the first order, collision front-front on the second-order, and side-by-side collision on the third order. The speed of vehicles has an impact on accidents.
\end{abstract}

Keywords: TCT, conflict, rider behavior, motorcycle

\section{Introduction}

Deaths caused by traffic accidents are quite numerous. In 2013 it recorded a total of 1.3 million people who were killed by traffic accidents in the world [6]. There are 88 countries that have sought to reduce the number of deaths caused by traffic accidents. However, the number of deaths is still very high as much as 1.2 million per year [4]. The traffic accident is at the 8th position of the cause of death of all ages [5].

The number of traffic accidents in Indonesia in 2012-2017 is experiencing ups and downs. In 2012 it recorded 117 thousand cases of accidents. Then there was a decline in the year 2014 with 95 thousand cases. However, the increase came back up until the year 2016 recorded 106 thousand cases and again experiencing a decline in the year 2017 with a total of 103 thousand [1]. Bekasi has a population of 301 thousand inhabitants. Judging from the data, the total population of bekasi is fairly dense. In addition, Bekasi is one of the connecting city or entrance to the capital. So Bekasi has a traffic density that becomes one of the factors causing traffic accidents. Data obtained from March 2017 to March 2018 recorded 819 cases of accident. Most accident cases occurred in September 2017 with the amount of 85 cases [3].

The problem identification on this research is that motorcyclists are still many who are not orderly in driving. In addition, the Narogong highway is the way for the dual axle trucks (heavy vehicles) that make physical and geometric conditions on the Narogong road segment often damaged.

The purpose of this research is to know the safety of road users on the road of Narogong, analyze the influence of motorcyclists against accidents on Narogong Highway and provide solutions in the handling of accidents on the road Narogong Highway. 


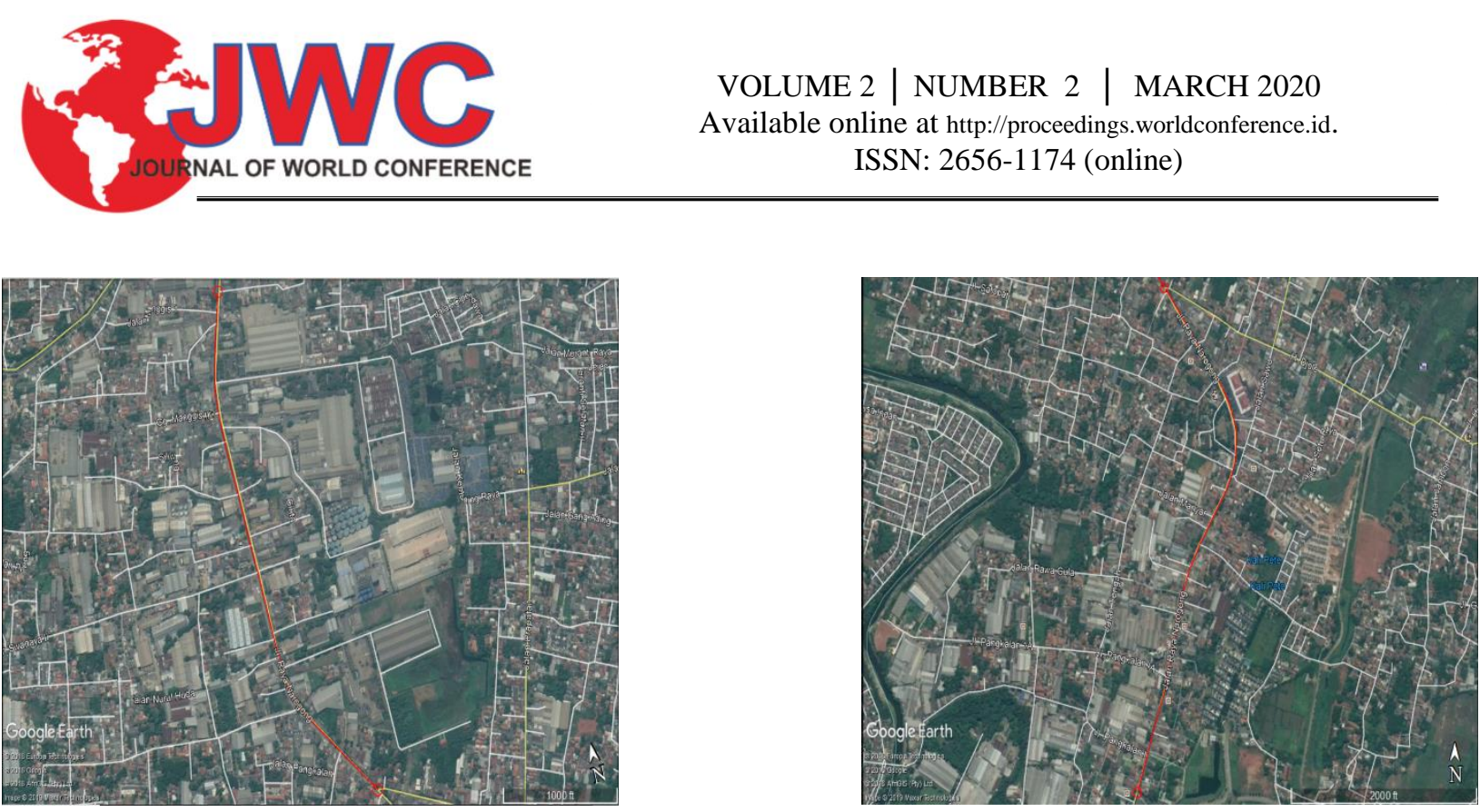

Figure 1. Segment 1 and Segment 2 research locations

Source: Personal Data, 2019

\section{Methodology}

The method of analysis used is a quantitative method that serves to calculate the number of conflicts occurring on the research site. Where this method consists of several stages:

a. Preparations discussing preliminary surveys.

b. Data collection that discusses how.

c. Analysis stage that discusses the calculation of traffic volume, speed and conflict that occurred.

The data required in this study included crash data in the last 5 years, and survey data conducted (traffic volume, vehicle speed and mobility movement) that caused the conflict.

\section{Results and Discussion}

a. Calculation of traffic volume

Recapitulation result of traffic volume calculation at research location using Manual Road capacity Indonesia (MKJI) 1997 [2] presented in table 1.

Table 1. Recapitulation of traffic Volume calculation results

\begin{tabular}{|c|c|c|c|c|c|c|}
\hline Time & Segment & Direction & $\begin{array}{c}\text { Total } \\
\text { (direction) }\end{array}$ & Total (segment) & Difference & Total \\
\hline & & & smp/jam & smp/jam & smp/jam & smp/jam \\
\hline \multirow{4}{*}{ 09.00-10.00 } & 1 & Bekasi & 1800 & & \multirow{4}{*}{25,3} & \multirow{4}{*}{7401,9} \\
\hline & 1 & Bogor & 1888,3 & 3688,3 & & \\
\hline & & Bekasi & 1811,0 & & & \\
\hline & 2 & Bogor & 1902,6 & $3 / 13,6$ & & \\
\hline \multirow{4}{*}{$14.00-15.00$} & 1 & Bekasi & 1837,7 & 36776 & \multirow{4}{*}{23,3} & \multirow{4}{*}{7378,5} \\
\hline & 1 & Bogor & 1839,9 & $36 / 7,6$ & & \\
\hline & 2 & Bekasi & 1851 & 37009 & & \\
\hline & 2 & Bogor & 1850,1 & $3 / 00,9$ & & \\
\hline
\end{tabular}

Source: Personal Data, 2019

Based on table 1, the results of Segment 1 and Segment 2 have the most populous traffic volume towards Bekasi at 14.00-15.00 WIB at 1851 SMP/hr, while the most populous traffic volume towards Bogor at 09.0010.00 WIB at 1902.6 SMP/hr.

b. Vehicle speed calculation

Recapitulation of vehicle speed calculation results in the research location is presented in table 2 and table 3. 


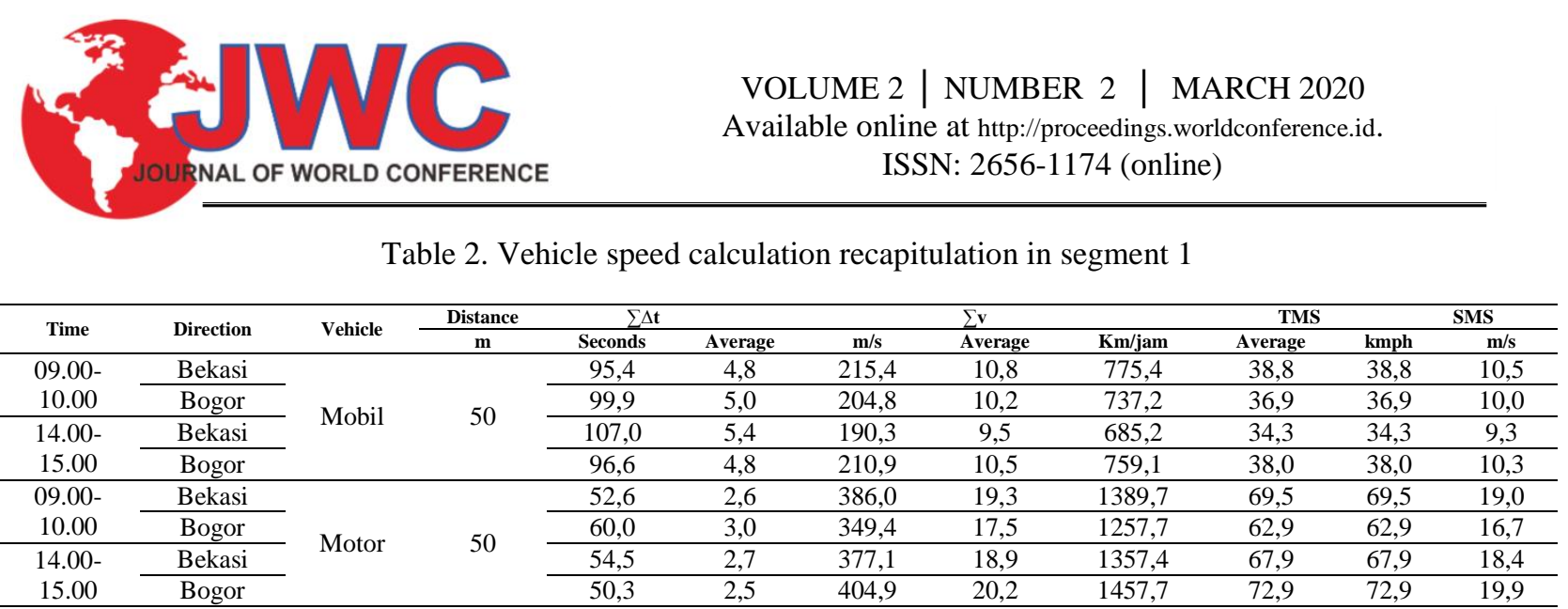

Source: Personal Data, 2019

Tabel 3. Vehicle speed calculation recapitulation in segment 2

\begin{tabular}{|c|c|c|c|c|c|c|c|c|c|c|c|}
\hline \multirow{2}{*}{ Time } & \multirow{2}{*}{ Direction } & \multirow{2}{*}{ Vehicle } & Distance & \multicolumn{2}{|c|}{$\sum \Delta \mathbf{t}$} & \multicolumn{4}{|c|}{$\sum \mathbf{v}$} & TMS & \multirow{2}{*}{$\begin{array}{c}\mathrm{SMS} \\
\mathrm{m} / \mathrm{s}\end{array}$} \\
\hline & & & $\mathbf{m}$ & Seconds & Average & $\mathrm{m} / \mathrm{s}$ & & & Km/jam & Average & \\
\hline 09.00- & Bekasi & \multirow{4}{*}{ Mobil } & \multirow{4}{*}{50} & 91,1 & 4,6 & 224,7 & 11,2 & 808,9 & 40,4 & 40,4 & 11,0 \\
\hline 10.00 & Bogor & & & 102,1 & 5,1 & 199,4 & 10,0 & 717,9 & 35,9 & 35,9 & 9,8 \\
\hline $14.00-$ & Bekasi & & & 104,1 & 5,2 & 193,6 & 9,7 & 697,0 & 34,8 & 34,8 & 9,6 \\
\hline 15.00 & Bogor & & & 98,2 & 4,9 & 210,0 & 10,5 & 755,9 & 37,8 & 37,8 & 10,2 \\
\hline 09.00- & Bekasi & \multirow{4}{*}{ Motor } & \multirow{4}{*}{50} & 50,2 & 2,5 & 404,4 & 20,2 & 1456,0 & 72,8 & 72,8 & 19,9 \\
\hline 10.00 & Bogor & & & 61,0 & 3,1 & 346,7 & 17,3 & 1248,2 & 62,4 & 62,4 & 16,4 \\
\hline $14.00-$ & Bekasi & & & 53,3 & 2,7 & 388,3 & 19,4 & 1397,8 & 69,9 & 69,9 & 18,8 \\
\hline 15.00 & Bogor & & & 51,0 & 2,5 & 401,6 & 20,1 & 1445,6 & 72,3 & 72,3 & 19,6 \\
\hline
\end{tabular}

Source: Personal Data, 2019

Based on table 2 and table 3 you get the result of speed calculations on the research location. In segment 1 the car and motorcycle vehicles heading to Bekasi has the highest average speed at 09.00-10.00 for 38.8 kmph (car) and $69.5 \mathrm{kmph}$ (motor), while the one towards Bogor has the highest average speed on At 14.0015.00 for $38.0 \mathrm{kmph}$ (car) and $72.9 \mathrm{kmph}$ (motor). In segment 2, vehicles heading to Bekasi have the highest average speed at $09.00-10.00$ for $40.4 \mathrm{kmph}$ (car) and $72.8 \mathrm{kmph}$ (motor), furthermore, the vehicles heading towards Bogor have the highest average speed at 14.00-15.00 for $37.8 \mathrm{kmph}$ (car) and $72.3 \mathrm{kmph}$ (motor).

c. Collection of conflict data

To find out the conflicts that occurred at the research site, a grouping of conflict variations aimed to facilitate the retrieval of data for various conflicts. Variations of conflicts were observed in the movement of motorcycle vehicles against KR, KBM, BB and TB.

Recapitulation result of conflict data collection that occurs at the research location is presented in table 4.

Table 4. Recapitulation of data collection results of conflict groups 1 and 2

\begin{tabular}{|c|c|c|c|c|c|c|c|}
\hline Conflict & \multirow[b]{2}{*}{ Directions } & \multicolumn{2}{|c|}{ Total conflicts } & \multicolumn{2}{|c|}{ Presentations } & \multicolumn{2}{|c|}{ Total } \\
\hline $\begin{array}{ll}\text { Conflict Group } 1 & \text { Conflict Group } 2 \\
(1-12 \text { variations }) & (13-21 \text { variations })\end{array}$ & & Segment 1 & Segment 2 & Segment 1 & Segment 2 & Conflicts & Presentations \\
\hline Front-side (variation 1-4) & \multirow{6}{*}{ Bekasi } & 93 & 88 & $17 \%$ & $17 \%$ & 181 & $17 \%$ \\
\hline Side side (Variation 7-10) & & 45 & 37 & $8 \%$ & $7 \%$ & 82 & $8 \%$ \\
\hline Front-Front (Variation 5, 6, 11,12) & & 59 & 40 & $11 \%$ & $8 \%$ & 99 & $9 \%$ \\
\hline Continuous collision (13-19 variations) & & 27 & 34 & $5 \%$ & $7 \%$ & 61 & $6 \%$ \\
\hline Front-back (13 variations) & & 48 & 39 & $9 \%$ & $8 \%$ & 87 & $8 \%$ \\
\hline Pedestrians (Variation $20 \& 21$ ) & & 13 & 4 & $2 \%$ & $1 \%$ & 17 & $2 \%$ \\
\hline Front-side (variation 1-4) & \multirow{7}{*}{ Bogor } & 71 & 118 & $13 \%$ & $23 \%$ & 189 & $18 \%$ \\
\hline Side side (Variation 7-10) & & 62 & 28 & $11 \%$ & $5 \%$ & 90 & $8 \%$ \\
\hline Front-Front (Variation 5, 6, 11,12) & & 56 & 60 & $10 \%$ & $12 \%$ & 116 & $11 \%$ \\
\hline Continuous collision (13-19 variations) & & 40 & 26 & $7 \%$ & $5 \%$ & 66 & $6 \%$ \\
\hline Front-back (13 variations) & & 40 & 40 & $7 \%$ & $8 \%$ & 80 & $7 \%$ \\
\hline Pedestrians (Variation $20 \&$ 21) & & 7 & 3 & $1 \%$ & $1 \%$ & 10 & $1 \%$ \\
\hline$\sum$ & & 561 & 517 & & & 1078 & $100 \%$ \\
\hline
\end{tabular}

Source: Personal Data, 2019 


\section{Conclusions}

Based on data and the results of the survey data processing, can be concluded in several ways below:

1. The location of the study of the Narogong Highway (after a flyover Cipendawa until the junction of three houses Vida) after the survey conducted using the TCT method, resulted that the location is potentially to cause accidents. Thus, this method can be used in order to improve the safety and security of road users.

2. To determine the observation point, it can be assumed alone. The results of the observations were:

a. In Segment 1 and Segment 2, frequent conflict variations include a side-front collision of 17\% (segment 1) and $13 \%$ (segment 2). The largest number of conflicts occurred at 09.00-10.00.

b. The most populous Volume of traffic in Segment 1 and Segment 2, occurred at 09.00-10.00 for 7401.9 SMP/hr.

c. In segment 1 the car and motorcycle vehicles heading to Bekasi has the highest average speed at 09.00-10.00 for $38.8 \mathrm{kmph}$ (car) and $69.5 \mathrm{kmph}$ (motor), while the one towards Bogor has the highest average speed on At 14.00-15.00 for $38.0 \mathrm{kmph}$ (car) and $72.9 \mathrm{kmph}$ (motor). Furthermore, in segment 2 of the vehicle leading to Bekasi has the highest average speed at 09.00-10.00 for $40.4 \mathrm{kmph}$ (car) and $72.8 \mathrm{kmph}$ (motor), whereas, the vehicle that led towards Bogor has the highest average speed at At 14.00-15.00 for $37.8 \mathrm{kmph}$ (car) and $72.3 \mathrm{kmph}$ (motor).

3. To reduce the occurrence of conflicts, some things that can be done are:

a. Segregation of motorcycle lanes with other vehicles.

b. The new markings are so that each vehicle from the opposite direction stays on track and the route.

c. Addition/Update traffic signs because many of the signs are outdated/not feasible.

d. Traffic lights at the junction of Gg. Sawo (Bantargebang Market) is more optimised, so there is no volume buildup of vehicles. Traffic lights at the junction of Gg. Sawo (Bantargebang Market) is more optimised, so there is no volume buildup of vehicles.

Conflicts occur not only due to the unawareness of the driver of the vehicle, but due to the insufficient geometric conditions of the road when viewed from the existing road facilities.

\section{References}

[1] Badan Pusat Statistik. (2019, September 8). Tabel Dinamis. Retrieved September 8, 2019, from Jumlah Kecelakaan, Korban Mati, Luka Berat, Luka Ringan, dan Kerugian Materi 2013-2017: https://bps.go.id/site/resultTab

[2] Departemen Pekerjaan Umum. (1997). Manual Kapasitas Jalan Indonesia. Jakarta: Kementrian Pekerjaan Umum.

[3] POLRES METRO BEKASI. (2019, September 9). Data Statistik Kasus. Retrieved September 9, 2019, from POLRES METRO BEKASI: http://www.polresmetrobekasi.id/data-statistik-kasus.html

[4] World Health Organization. (2013). Global Status Report on Road Safety 2013 : Supporting a Decade of Action. Geneva: World Health Organization.

[5] World Health Organization. (2018). Global Status Report on Road Safety 2018. France: World Health Organization.

[6] World Health Organization. (2019, September 8). Global Health Observatory (GHO) data. Retrieved September 8, 2019, from World Health Organization: https://www.who.int/gho/road_safety/en/

\section{Biographies}

Andri Irfan, Rifai Engineering Lecturer at Mercu Buana University, Chair of Bachelor Program in Civil Engineering at the International University of Batam, Project Manager of the Infrastructure Rehabilitation and Reconstruction Project for affected areas in Palu, head of the PJN Region 3 Work Unit of West Java Province. 
Finsa Aziz, Fernanda born in Jakarta, November $20^{\text {th }}$, 1996. Is a student at Mercu Buana University in Bekasi with a Civil Engineering study program. Before majoring in Bachelor of civil engineering the writer completed his education in 2018 at D3 Transportation of Civil Engineering Sebelas Maret University Surakarta. After graduating, continued his education at Mercu Buana University in 2018. During the lecture, the writer was active in various campus activities such as Civil Week, Civil Expo, Seminars, training events and public lectures. 